\title{
Water Temperature and Baseflow Discharge of Streams Throughout the Range of Rio Grande Cutthroat Trout in Colorado and New Mexico-2010 and 2011
}

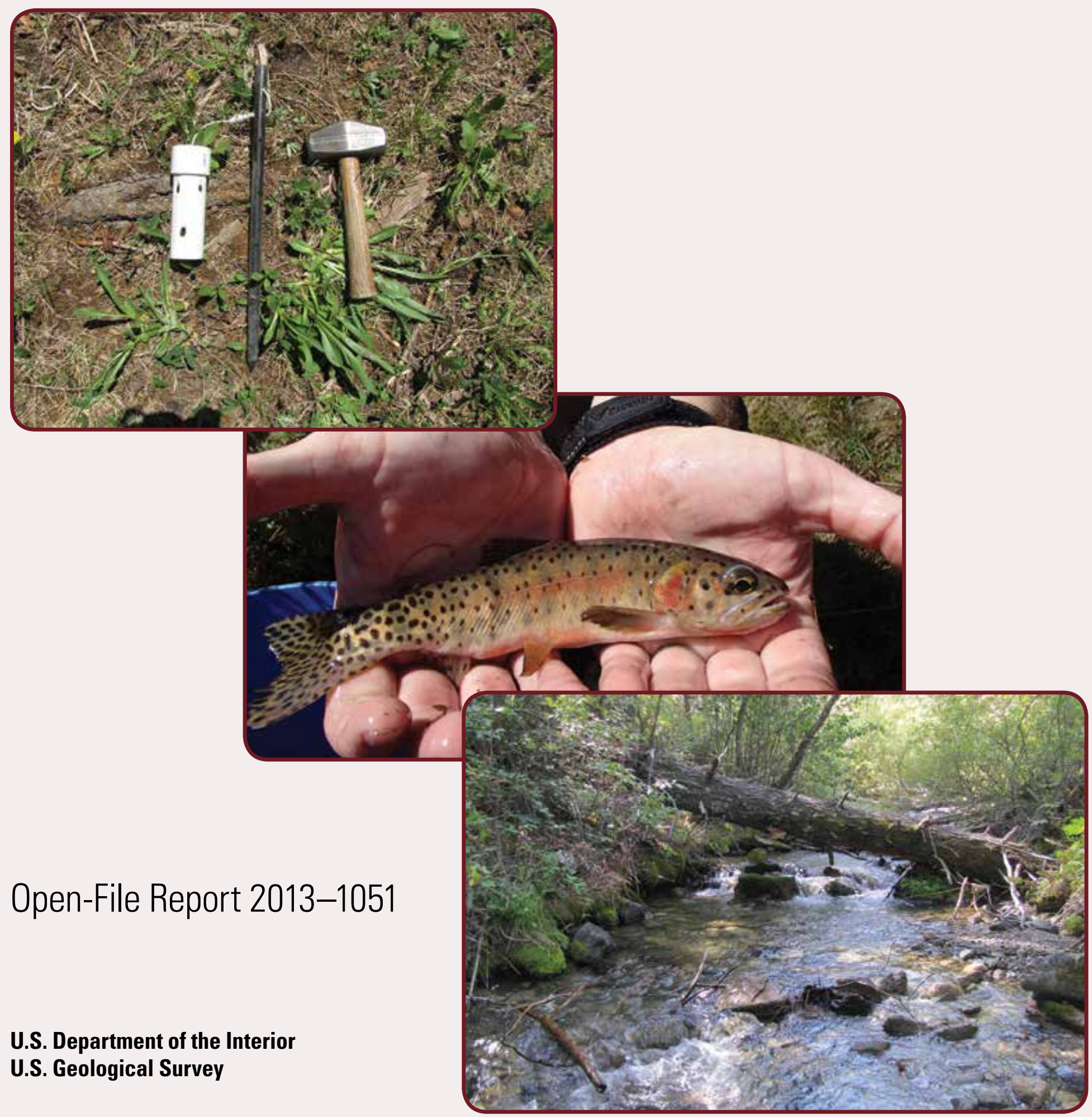





\section{Water Temperature and Baseflow Discharge of Streams Throughout the Range of Rio Grande Cutthroat Trout in Colorado and New Mexico-2010 and 2011}

By Matthew P. Zeigler, Andrew S. Todd, and Colleen A. Caldwell

Open-File Report 2013-1051 


\title{
U.S. Department of the Interior \\ SALLY JEWELL, Secretary
}

\section{U.S. Geological Survey Suzette M. Kimball, Acting Director}

\section{U.S. Geological Survey, Reston, Virginia: 2013}

\author{
This and other USGS information products are available at http://store.usgs.gov/ \\ U.S. Geological Survey \\ Box 25286, Denver Federal Center \\ Denver, CO 80225 \\ To learn about the USGS and its information products visit http://www.usgs.gov/ \\ 1-888-ASK-USGS
}

\footnotetext{
Any use of trade, product, or firm names is for descriptive purposes only and does not imply endorsement by the U.S. Government.

Although this report is in the public domain, permission must be secured from the individual copyright owners to reproduce any copyrighted materials contained within this report.
}

Suggested citation:

Zeigler, M.P., Todd, A.S., and Caldwell, C.A., 2013, Water temperature and baseflow discharge of streams throughout the range of Rio Grande cutthroat trout in Colorado and New Mexico-2010 and 2011: U.S. Geological Survey OpenFile Report 2013-1051, 18 p., http://pubs.usgs.gov/of/2013/1051/. 


\section{Acknowledgments}

Funding for this project was supported by the U.S. Geological Survey Science Support Partnership, the USGS Climate Change and Wildlife Science Center, and T\&E, Inc. Additional support was provided by New Mexico State University, Agricultural Experiment Station, and the Department of Fish, Wildlife and Conservation Ecology. We would also like to thank R. Galindo and S. Hall for field assistance as well as K. Patten (New Mexico Department of Game and Fish), J. Alves (Colorado Division of Wildlife), D. Storch (U.S. Forest Service), C. Cook (U.S. Forest Service), and S. Oetker (U.S. Fish and Wildlife Service) for valuable information of study streams and logistical support. 



\section{Contents}

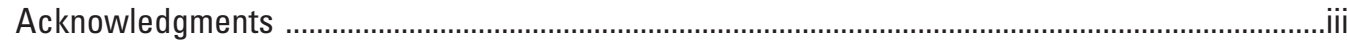

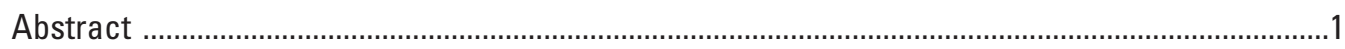

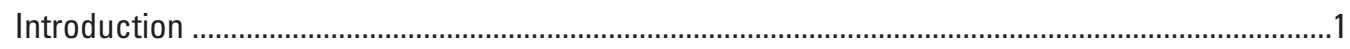

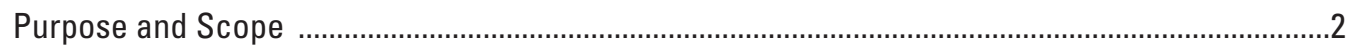

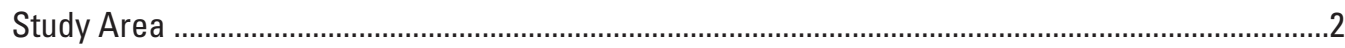

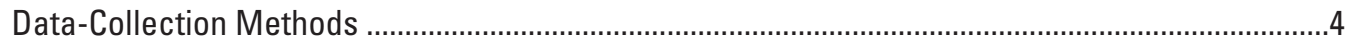

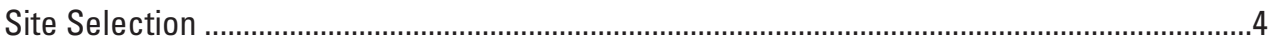

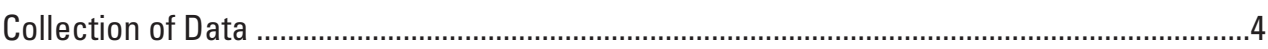

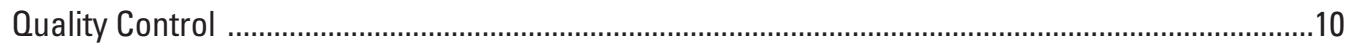

Stream and Air Temperature Data ....................................................................................

Stream-Discharge Data ..............................................................................................

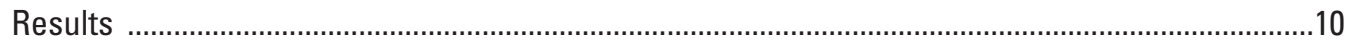

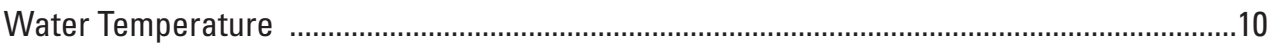

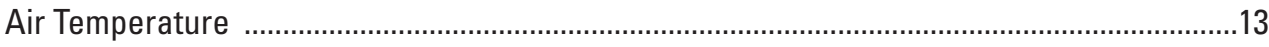

Comparison with Colorado's Water Temperature Criteria ....................................................13

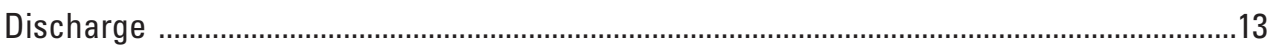

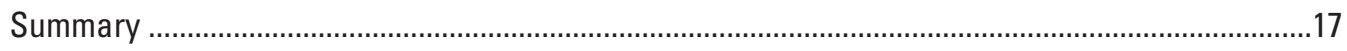

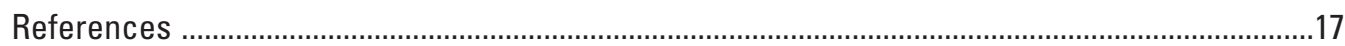

Appendix A: Monitoring Site Data for Rio Grande Cutthroat Trout Populations (two parts available online at http://pubs.usgs.gov/of/2013/1051//

\section{Figures}

1. Map showing historical range of Rio Grande cutthroat trout and monitoring sites within selected fourth level (8-digit) hydrological units .3

2. Map showing location of monitoring sites and documented Rio Grande cutthroat trout (RGCT) populations within the historical range of the subspecies

3. Graphs showing weekly average temperature (WAT) within streams containing Rio Grande cutthroat trout (WAT is calculated as the 7-day running average of the daily average temperature for that day and the prior 6 days)

4. Graphs showing daily maximum (DM) temperatures as measured in three regions within the distribution of Rio Grande cutthroat trout (DM is the maximum daily value of the running 2-hour average)

5. Graphs showing summary water temperature metrics calculated from water temperature datasets collected in 2010 and 2011

6. Graphs showing flow hydrographs for U.S. Geological Survey or Colorado Division of Water Resources monitored gage stations (within or in close proximity to Rio Grande cutthroat trout streams) used for comparison of measured discharge values in this study

7. Graphs showing measured baseflow discharge at sites within occupied Rio Grande cutthroat trout streams: $A, 2010(\mathrm{n}=54)$ and $B, 2011(\mathrm{n}=90)$ 


\section{Table}

1. Landscape, stream temperature, and summer baseflow metrics for study streams within the current distribution of Rio Grande cutthroat trout

\section{Conversion Factors}

\section{SI to Inch/Pound}

\begin{tabular}{lcl}
\hline \multicolumn{1}{c}{ Multiply } & By & \multicolumn{1}{c}{ To obtain } \\
\hline centimeter $(\mathrm{cm})$ & Length & inch (in.) \\
millimeter $(\mathrm{mm})$ & 0.3937 & inch (in.) \\
meter $(\mathrm{m})$ & 0.03937 & foot (ft) \\
kilometer $(\mathrm{km})$ & 3.281 & mile (mi) \\
\hline & 0.6214 & \\
\hline hectare $(\mathrm{ha})$ & Area & acre \\
square kilometer $\left(\mathrm{km}^{2}\right)$ & 2.471 & acre \\
\hline & 247.1 & foot per second $(\mathrm{ft} / \mathrm{s})$ \\
\hline meter per second $(\mathrm{m} / \mathrm{s})$ & Flow rate & cubic foot per second $\left(\mathrm{ft}^{3} / \mathrm{s}\right)$ \\
cubic meter per second $\left(\mathrm{m}^{3} / \mathrm{s}\right)$ & 3.281 & \\
\hline
\end{tabular}

Temperature in degrees Celsius $\left({ }^{\circ} \mathrm{C}\right)$ may be converted to degrees Fahrenheit $\left({ }^{\circ} \mathrm{F}\right)$ as follows:

$$
{ }^{\circ} \mathrm{F}=\left(1.8 \times{ }^{\circ} \mathrm{C}\right)+32
$$

Vertical coordinate information is referenced to the insert datum name (and abbreviation) here, for instance, "North American Vertical Datum of 1988 (NAVD 88)"

Horizontal coordinate information is referenced to the insert datum name (and abbreviation) here, for instance, "North American Datum of 1983 (NAD 83)" 


\title{
Water Temperature and Baseflow Discharge of Streams Throughout the Range of Rio Grande Cutthroat Trout in Colorado and New Mexico-2010 and 2011
}

\author{
By Matthew P. Zeigler, Andrew S. Todd, and Colleen A. Caldwell
}

\section{Abstract}

This study characterized the thermal regime in a number of Colorado and New Mexico streams that contain populations of Rio Grande cutthroat trout and had no previous record of continual temperature records. When compared to Colorado's water temperature criteria (Cold Tier 1), a portion of these populations appeared to be at risk from elevated stream temperatures, as indicated by exceedance of both acute (17-22 percent) and chronic (2-9 percent) water quality metrics. Summer water temperature profiles recorded at sites within current Rio Grande cutthroat trout habitat indicated that although the majority of currently occupied conservation streams have temperatures that fall well below these biologically based acute and chronic thermal thresholds, several sites may be at or approaching water temperatures considered stressful to cutthroat trout. Further, water temperatures should be considered in decisions regarding the current and future thermal suitability of potential Rio Grande cutthroat trout restoration sites. Additionally, baseflow discharge sampling indicated that a majority of the sampled stream segments containing Rio Grande cutthroat trout have flows less than 1.0 cubic feet per second (cfs) in both 2010 (74 percent) and 2011 (77 percent). The relative drought sensitivity of these low baseflow streams containing Rio Grande cutthroat trout should be further evaluated to assess their probable sustainability under possible future drought conditions.

\section{Introduction}

The Rio Grande cutthroat trout (Oncorhynchus clarkii virginalis) is the southernmost subspecies of cutthroat trout, endemic to the Rio Grande, Canadian, and Pecos River Basins of New Mexico and southern Colorado (Behnke, 2002). Currently, the Rio Grande cutthroat trout occupies approximately 12 percent of its historical distribution (Alves and others, 2008), having lost historical habitat through introduction of nonnative salmonids and human-made habitat alterations (Pritchard and Cowley, 2006). This contraction of available habitat has fragmented historically interconnected populations, isolating the majority of remaining populations to high elevation (above 2,500 meters [m]) headwater streams (Alves and others, 2008). Many of these remaining populations are at risk of extirpation because of one or more risks including low population densities, reduced lengths of occupied stream habitat, nonnative trout, or climate change (U.S. Federal Register, 2008). A recent status review found that listing the subspecies under the Endangered Species Act of 1973 was warranted but precluded by higher priority actions.

An important, yet largely uncharacterized, threat to the subspecies is the potential effects of future climate change. Average global air temperature is projected to increase up to 4 degrees Celsius $\left({ }^{\circ} \mathrm{C}\right)$ (relative to $1980-1999$ period) by the end of the 21st century (Intergovernmental Panel on Climate Change, 2007), a change which could have devastating effects on aquatic ecosystems through altered stream temperature and hydrological regimes (as in shifts in the timing and magnitude of snowmelt), as well as contributing to an anticipated increase in the frequency and intensity of stochastic events such as wildfire, drought, and flooding. Recent investigation into climate change within the historical range of Rio Grande cutthroat trout has indicated that since 1963, significant increases in air temperature, shifts in the hydrological regime, and decreases in snowpack have already occurred across the range of the subspecies (Zeigler and others, 2012).

Temperature influences almost all life-cycle aspects of fish and ultimately defines the relative thermal suitability of a given habitat for a particular species (Magnuson and others, 1979). For example, temperatures above the optimal range of a subspecies can increase metabolic demand and cause decreases in growth if food intake does not compensate for the increase in metabolic demand (Jobling, 1997). Rio Grande cutthroat trout are stenothermic ectotherms, requiring cold water habitats to survive. Water temperature can also influence interactions with other fish (De Staso and Rahel, 1994), distribution (Dunham and others, 2003), reproductive success (Winkle and others, 1997), and ultimately survival (Bear and others, 2007). As such, warming stream temperatures 
can decrease habitat available for salmonids by increasing temperature above the suitable thermal range for the species. In extreme cases, warming stream temperatures can render particular stream reaches or even entire streams uninhabitable. Laboratory studies have indicated that Rio Grande cutthroat trout have a 30-day (d) ultimate upper incipient lethal temperature (UUILT, temperature lethal to 50 percent of the population) of $22.1{ }^{\circ} \mathrm{C}$, similar to other subspecies of cutthroat trout, but cooler than the upper thermal limits of nonnative salmonids that occur in the current range of the subspecies (Zeigler, 2012).

Stream discharge is also important in determining growth, survival, and distribution of salmonids, as many critical life history components (such as spawning) are linked to specific flow regimes and time-dependent cues (Behnke, 2002). For example, decreased baseflows limited growth in some salmonids (Harvey and others, 2006), and fish size has also been positively linked to the size of available pools (Harvey and Stewart, 1991). Low to no discharge can affect flow-sensitive riffle habitat with a concurrent loss of hydrological connectivity (Lake, 2003). In the Southwest United States, precipitation is expected to decrease in the future, thereby increasing drought severity and drought length (Hoerling and Eischied, 2007). We anticipate that alterations to the hydrological cycle, caused by changes in precipitation, may reduce baseflow to the point of limiting occupiable habitat of Rio Grande cutthroat trout.

As detailed above, the importance of temperature and flow regimes on the survival and success of salmonid populations is unequivocal. In addition to the effects on stream-dwelling fishes, reduced discharge can influence water temperatures as smaller water volumes are more easily heated by warm air temperatures and solar radiation (Webb and others, 2008). Prior to this study little data on current thermal regimes and baseflow discharge had been systematically collected within the majority of streams currently occupied by Rio Grande cutthroat trout. Understanding existing thermal and baseflow conditions experienced by the subspecies in streams where populations occur is important in evaluating the vulnerability of the subspecies to climate-related changes as well as providing resource managers with information to assess the climate-related suitability of potential restoration streams. To facilitate key resource management decisions, a comprehensive monitoring network of a total of 69 sites located within currently occupied and potential Rio Grande cutthroat trout restoration streams was established in the spring of 2010. This network was expanded to 108 sites by the fall of 2011.

In 2007, Colorado revised its statewide water quality criteria for water temperature based on a rigorous review of the literature that addressed the thermal requirements of fish species residing in Colorado (Todd and others, 2008). The purpose of the development of these criteria was to protect resident fish, including native species such as cutthroat trout, from acute and chronic thermal stress. Although these temperature criteria have yet to be implemented as site-specific standards within the Rio Grande watershed in Colorado and do not apply in New Mexico, they are used herein as a comparison point between existing thermal conditions documented within streams containing Rio Grande cutthroat trout and biologically based thermal thresholds.

\section{Purpose and Scope}

In this report, we focus on water temperature and baseflow hydrology as "climate-sensitive" environmental variables within a network of 108 sites throughout the current geographic distribution of Rio Grande cutthroat trout. Reported data were collected between May 2010 and October 2011 (most recent analysis at the time of this report). Not all sites have data for all years because of the gradual expansion of this network and the occasional loss of data loggers at individual sites. This report (1) summarizes all water and air temperature data collected in watersheds within the current distribution of the Rio Grande cutthroat trout, (2) summarizes site-specific water temperature metrics, (3) compares these summary metrics to biologically based water temperature thermal criteria, and (4) lists all baseflow hydrology measurements within the network.

\section{Study Area}

The historical range of the Rio Grande cutthroat trout encompasses approximately 214,000 square kilometers $\left(\mathrm{km}^{2}\right)$ in northern New Mexico and southern Colorado (fig. 1) and includes the Rio Grande (8,689 kilometers $(\mathrm{km}))$ and Pecos $(1,002 \mathrm{~km})$ River Basins from their headwaters to the Texas border and the majority of the Canadian River $(1,026 \mathrm{~km})$ Basin in New Mexico. Historically, Rio Grande cutthroat trout are thought to have occupied approximately $10,700 \mathrm{~km}$ of streams within this large geographic area. Historical habitat was equally split between Colorado (48.5 percent) and New Mexico (51.5 percent), although more geographical area occurs in New Mexico (Alves and others, 2008).

At the time of this report, the subspecies occurs within approximately 12 percent $(1,302 \mathrm{~km})$ of its historical habitat (Alves and others, 2008). The majority of this currently occupied habitat occurs in northern New Mexico and southern Colorado within the high elevation (1,829 $\mathrm{m}$ to $3,810 \mathrm{~m})$ headwater streams of the Sangre de Cristo, Jemez, and San Juan Mountain Ranges. Although one small restored population of Rio Grande cutthroat trout occurs south of Albuquerque, N. Mex., the majority of historical and present habitat occurs in northern New Mexico and southern Colorado. Thus, the study has focused primarily within these areas. Land ownership across the current distribution of Rio Grande cutthroat trout consists primarily of U.S. Forest Service (54 percent), private land (41 percent), National Park Service (2 percent), and U.S. Bureau of Land Management, Tribal, and State-owned lands (about 1 percent each) (Alves and others, 2008). 


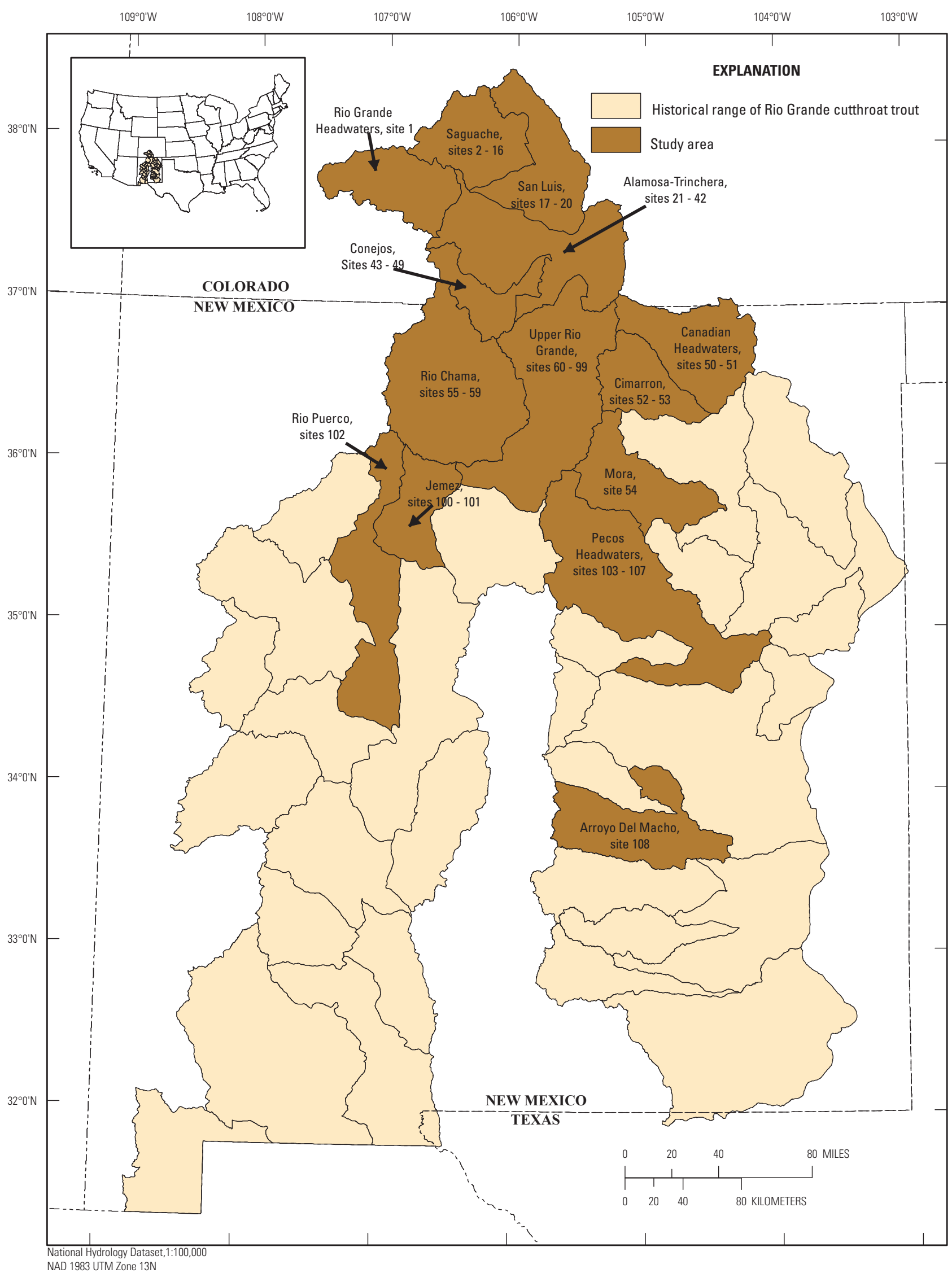

Figure 1. Historical range of Rio Grande cutthroat trout and monitoring sites within selected fourth level (8-digit) hydrological units. 


\section{Data-Collection Methods}

\section{Site Selection}

Selection of study streams was informed by collaborative input provided by parties signatory to the Rio Grande Cutthroat Trout Conservation Agreement (hereafter referred to as "Agreement"), including the New Mexico Department of Game and Fish (NMDGF), Colorado Parks and Wildlife (CPW), the U.S. Forest Service (Santa Fe, Carson, and Rio Grande National Forests), the National Park Service (Great Sand Dunes National Park), local tribes (the Mescalero Apache Nation), and the U.S. Fish and Wildlife Service (USFWS) (RGCT Conservation Team, 2009). Initial selection of study streams was based on current Rio Grande cutthroat trout populations characterized by the signatories as "high quality" based on genetic purity, lack of nonnative salmonids, and population size. Importantly, these streams were selected from a database of streams previously identified as containing Rio Grande cutthroat trout by signatories to the agreement, and independent validation of the presence of the fish was not conducted as part of this study. After initial site selection, several additional streams were added on the basis of requests from these State, Federal, and Tribal managers, including potential restoration sites, current restoration sites, or populations thought to be at risk because of a variety of threats related to future climate change.

In total, 108 sites were selected for study of which 97 sites fall within currently identified conservation populations which defines the continuous extent of a population of Rio Grande cutthroat trout unhindered by complete barriers (Alves and others, 2008) (fig. 2; table 1). The remaining 11 stream sites were selected because they have been considered as potential restoration sites for Rio Grande cutthroat trout. Within each stream, at least one paired stream/air site was selected at or near the downstream extent of a given conservation population. In general, monitoring sites located at the lowest extent of Rio Grande cutthroat trout populations were within occupied habitat unless otherwise prevented (appendix A). Additional sites within a unique stream were selected on the basis of stream length and number of tributaries. For example, streams with occupied habitat of $8 \mathrm{~km}$ or greater, or those with unmonitored tributaries, warranted addition of sites to capture temperature variation because of the large spatial area. Within potential restoration streams, stream/air data loggers were deployed to correspond to elevations of data loggers within sites of nearby streams occupied by the subspecies.

\section{Collection of Data}

Certain stream conditions are known to cause thermal heterogeneity within a stream channel (such as tributaries, beaver ponds, groundwater seepages). To prevent deployment of data loggers into sites that would not accurately represent the thermal regime of the stream, data loggers were moved upstream or downstream to ensure thermal homogeneity. Study sites at population termini, however, were only moved upstream to ensure data loggers remained within occupied habitat. Temperature data loggers were deployed within the thalweg of deep wellmixed habitats (as in runs), usually within areas covered by riparian vegetation.

Data loggers were calibrated (see "Quality Control" section) then deployed between May 2010 and October 2011. Both air and stream temperature data loggers were programmed to record temperatures at 1-h intervals, an interval which has been demonstrated to have a small probability of missing true daily maximum temperatures, even within streams exhibiting high daily variation in water temperature (Dunham and others, 2005). Air and water data loggers were housed in 3.81 millimeter $(\mathrm{mm})$ white polyvinyl chloride (PVC) pipe to prevent physical damage and protect the data logger from direct exposure to solar radiation, which can bias temperature readings (Dunham and others, 2005). Holes were drilled along the PVC housings to ensure adequate flow-through of air and water. Stream housings were attached to predrilled metal stakes with coated copper wire and anchored within the stream thalweg with a sledgehammer. Air temperature data loggers were placed in housings within $50 \mathrm{~m}$ of the stream temperature logger and were suspended approximately $1.5 \mathrm{~m}$ above the ground on the north-facing side of a vegetative structure. Global Positioning System elevation and digital photographs were recorded for each stream/air temperature study site (see appendix A).

Sites were revisited in the falls of 2010 and 2011, and both stream and air temperature data loggers were downloaded. At the time of site revisits, stream-discharge rates were measured at each thermograph site to evaluate and compare baseflow rates between streams. Measurements of discharge were conducted by using the midsection method, where velocity measurements are taken at the linear midsection of predefined intervals within the stream channel. Where feasible, 15-20 intervals were established within a straight U-shaped channel section (Harrelson and others, 1994). If stream widths were too narrow to allow crosssection intervals of greater than 10 centimeters $(\mathrm{cm})$, fewer intervals were used (U.S. Environmental Protection Agency, 2004). Velocity measurements were taken at appropriate depths following the methods of Rantz and others, 1982. Discharge was measured by using either a Marsh-McBirney Flo-Mate (Model 2000) or a U.S. Geological Survey (USGS) Pygmy-MH Meter (Model 6225). 


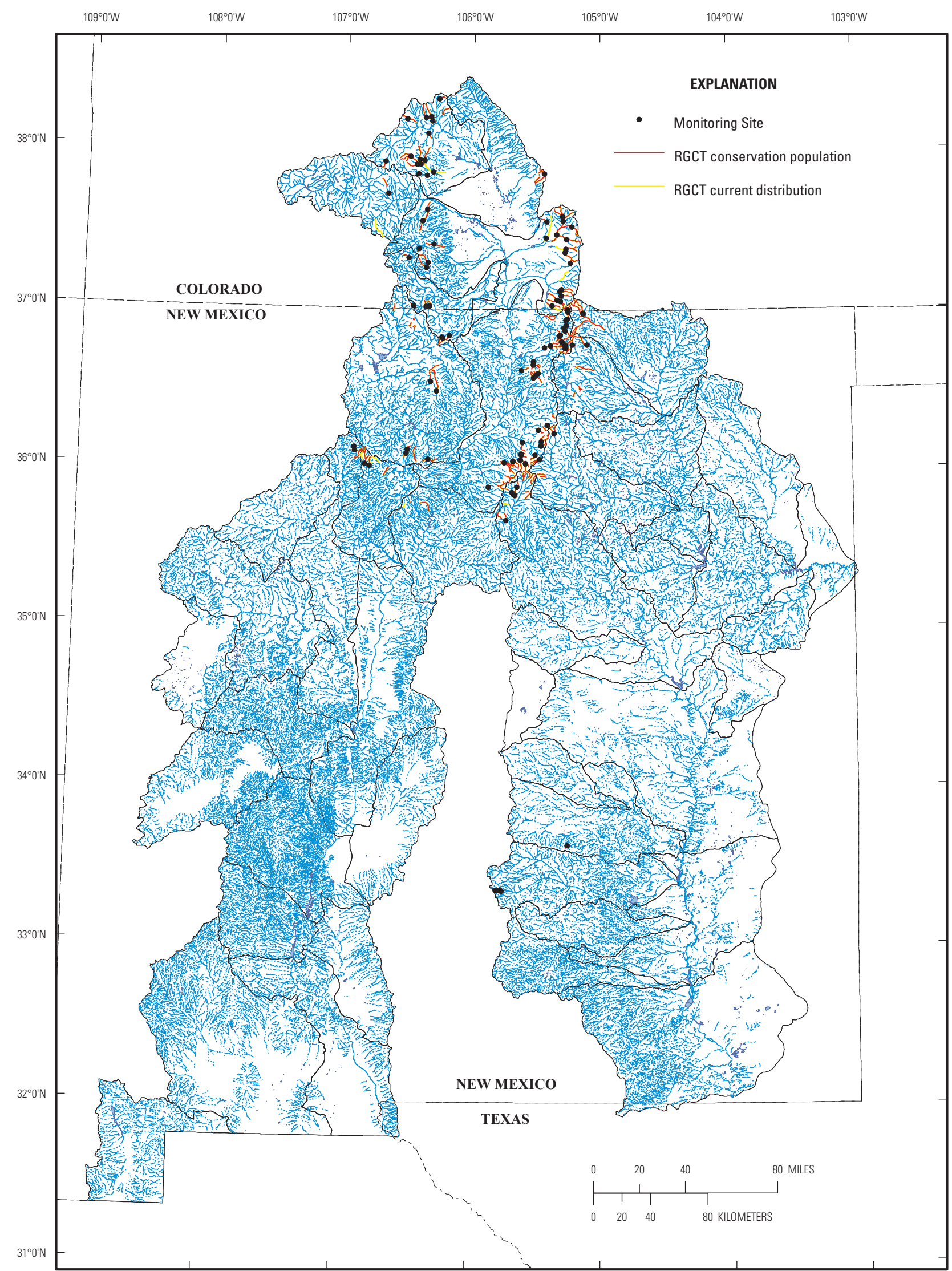

Figure 2. Location of monitoring sites and documented Rio Grande cutthroat trout (RGCT) populations within the historical range of the subspecies. 
Table 1. Landscape, stream temperature, and summer baseflow metrics for study streams within the current distribution of Rio Grande cutthroat trout. Values highlighted in red indicate water temperature values that exceed Colorado's Cold Water Tier 1 water temperature criteria (Todd and others, 2008). Values highlighted in blue indicate baseflow measurements determined "precipitation affected," as defined by the accumulation of more than $1.3 \mathrm{~cm}$ of precipitation measured at the nearest SNOw TELemetry station on the day of the discharge measurement combined with the 2 days prior.

[RGCT, Rio Grande cutthroat trout present (Y) or not present but considered potential restoration streams (N); Elevation (m), Drainage area (ha), 2-hr Max = yearly maximum 2-hour running mean; MWAT, maximum weekly average temperature; $\mathrm{Q}$ = summer baseflow discharge (cubic feet per second); "---" refers to data not collected; "Exposed" refers to a data logger that was exposed to air temperature at some point during the year and data is not reported; "Lost" refers to data loggers removed by vandalism or storm event]

\begin{tabular}{|c|c|c|c|c|c|c|c|c|c|c|}
\hline Site & $\begin{array}{l}\text { Stream name, } \\
\text { state }\end{array}$ & RGCT & $\begin{array}{l}\text { Elevation } \\
\text { (m) }\end{array}$ & $\begin{array}{c}\text { Drainage } \\
\text { area } \\
\text { (ha) }\end{array}$ & $\begin{array}{c}2-h r \text { max } \\
\left({ }^{\circ} \mathrm{C}\right) \\
2010\end{array}$ & $\begin{array}{c}\text { 2-hr max } \\
\left({ }^{\circ} \mathrm{C}\right) \\
2011\end{array}$ & $\begin{array}{c}\text { MWAT } \\
\left({ }^{\circ} \mathrm{C}\right) \\
2010\end{array}$ & $\begin{array}{c}\text { MWAT } \\
\left({ }^{\circ} \mathrm{C}\right) \\
2011\end{array}$ & $\begin{array}{c}0 \\
\text { (cfs) } \\
2010\end{array}$ & $\begin{array}{c}0 \\
\text { (cfs) } \\
2011\end{array}$ \\
\hline 1 & West Alder Creek, CO & Y & 2,654 & 5,018 & --- & 19.46 & --- & 14.40 & --- & 0.65 \\
\hline 2 & East Middle Creek, CO & Y & 3,002 & 1,420 & 16.01 & 15.65 & 11.85 & 11.72 & --- & 0.81 \\
\hline 3 & Jack's Creek, CO & $\mathrm{Y}$ & 2,518 & 7,720 & 22.07 & 20.57 & 16.15 & 14.81 & 0.14 & 0.34 \\
\hline 4 & Jack's Creek, CO & $\mathrm{Y}$ & 2,655 & 3,101 & 16.38 & 16.44 & 14.02 & 13.52 & 0.04 & 0.26 \\
\hline 5 & Cross Creek, $\mathrm{CO}$ & $\mathrm{Y}$ & 2,638 & 2,041 & 17.66 & Lost & 15.29 & Lost & 0.16 & 0.17 \\
\hline 6 & Big Spring Creek, CO & $\mathrm{Y}$ & 2,569 & 772 & --- & 20.57 & --- & 15.35 & 0.53 & 0.67 \\
\hline 7 & East Pass Creek, CO & $\mathrm{Y}$ & 2,789 & 1,302 & --- & 12.92 & --- & 11.52 & 0.04 & 0.08 \\
\hline 8 & Whale Creek, CO & Y & 3,144 & 1,279 & --- & --- & --- & --- & --- & 0.18 \\
\hline 9 & Carnero Creek, CO & $\mathrm{N}$ & 2,485 & 27,442 & 25.93 & 27.15 & 20.12 & 19.17 & 0.59 & 0.87 \\
\hline 10 & North Fork Carnero Creek, CO & $\mathrm{Y}$ & 2,703 & 6,131 & 20.33 & 14.92 & 14.57 & 12.44 & 0.07 & 0.05 \\
\hline 11 & South Carnero Creek, CO & $\mathrm{Y}$ & 2,681 & 10,984 & 22.29 & 21.12 & 17.18 & 16.72 & 0.87 & 1.39 \\
\hline 12 & Middle Fork Carnero Creek, CO & Y & 2,756 & 4,298 & 17.90 & 19.59 & 14.09 & 13.84 & 0.17 & 0.16 \\
\hline 13 & Cave Creek, $\mathrm{CO}$ & $\mathrm{Y}$ & 2,767 & 2,324 & 16.87 & 17.06 & 14.45 & 13.59 & 0.29 & 0.27 \\
\hline 14 & Prong Creek, CO & Y & 3,011 & 1,684 & 18.37 & 18.06 & 13.81 & 13.04 & 0.40 & 0.34 \\
\hline 15 & La Garita Creek, CO & $\mathrm{N}$ & 2,553 & 14,729 & 25.55 & 25.87 & 18.36 & 18.33 & --- & 2.96 \\
\hline 16 & La Garita Creek, CO & $\mathrm{N}$ & 2,690 & 10,647 & 22.12 & 22.13 & 15.99 & 15.91 & 2.80 & 2.79 \\
\hline 17 & Sand Creek, CO & $\mathrm{N}$ & 2,516 & 6,063 & --- & Lost & --- & Lost & --- & 11.8 \\
\hline 18 & Medano Creek, & Y & 2,583 & 4,167 & Lost & Lost & Lost & Lost & --- & 0.87 \\
\hline 19 & Medano Creek, CO & Y & 2,963 & 1,444 & --- & 15.08 & --- & 11.00 & --- & --- \\
\hline 20 & Little Medano Creek, CO & $\mathrm{Y}$ & 2,621 & 1,162 & --- & 10.31 & --- & 8.71 & --- & 0.60 \\
\hline 21 & Jim Creek, CO & $\mathrm{Y}$ & 2,964 & 2,596 & --- & --- & --- & --- & --- & 0.42 \\
\hline 22 & Torsido Creek, CO & $\mathrm{Y}$ & 2,961 & 2,193 & --- & --- & --- & --- & --- & 0.60 \\
\hline 23 & Rhodes Gulch, Co & $\mathrm{Y}$ & 2,960 & 713 & 13.62 & 15.44 & 9.90 & 11.02 & 0.42 & 0.44 \\
\hline 24 & Cat Creek, $\mathrm{CO}$ & Y & 2,683 & 2,080 & 18.20 & Exposed & 15.57 & Exposed & 0.02 & 0.04 \\
\hline 25 & San Francisco Creek, CO & Y & 2,533 & 3,636 & 16.51 & 15.86 & 14.10 & 14.23 & 1.17 & 0.74 \\
\hline 26 & San Francisco Creek, CO & $\mathrm{Y}$ & 2,920 & 1,281 & 13.33 & 14.76 & 9.17 & 9.87 & 1.92 & 1.24 \\
\hline 27 & Ute Creek, $\mathrm{CO}$ & $\mathrm{N}$ & 2,463 & 10,375 & 23.26 & Lost & 16.75 & Lost & 8.11 & 8.05 \\
\hline
\end{tabular}


Table 1. Landscape, stream temperature, and summer baseflow metrics for study streams within the current distribution of Rio Grande cutthroat trout. Values highlighted in red indicate water temperature values that exceed Colorado's Cold Water Tier 1 water temperature criteria (Todd and others, 2008). Values highlighted in blue indicate baseflow measurements determined "precipitation affected," as defined by the accumulation of more than $1.3 \mathrm{~cm}$ of precipitation measured at the nearest SNOw TELemetry station on the day of the discharge measurement combined with the 2 days prior. - Continued

[RGCT, Rio Grande cutthroat trout present (Y) or not present but considered potential restoration streams (N); Elevation (m), Drainage area (ha), 2-hr Max = yearly maximum 2-hour running mean; MWAT, maximum weekly average temperature; $\mathrm{Q}$ = summer baseflow discharge (cubic feet per second); "---" refers to data not collected; "Exposed" refers to a data logger that was exposed to air temperature at some point during the year and data is not reported; "Lost" refers to data loggers removed by vandalism or storm event]

\begin{tabular}{|c|c|c|c|c|c|c|c|c|c|c|}
\hline Site & $\begin{array}{l}\text { Stream name, } \\
\text { state }\end{array}$ & RGCT & $\begin{array}{l}\text { Elevation } \\
\text { (m) }\end{array}$ & $\begin{array}{c}\text { Drainage } \\
\text { area } \\
\text { (ha) }\end{array}$ & $\begin{array}{c}\text { 2-hr max } \\
\left({ }^{\circ} \mathrm{C}\right) \\
2010\end{array}$ & $\begin{array}{c}\text { 2-hr max } \\
\left({ }^{\circ} \mathrm{C}\right) \\
2011\end{array}$ & $\begin{array}{c}\text { MWAT } \\
\left({ }^{\circ} \mathrm{C}\right) \\
2010\end{array}$ & $\begin{array}{c}\text { MWAT } \\
\left({ }^{\circ} \mathrm{C}\right) \\
2011\end{array}$ & $\begin{array}{c}0 \\
\text { (cfs) } \\
2010\end{array}$ & $\begin{array}{c}0 \\
\text { (cfs) } \\
2011\end{array}$ \\
\hline 28 & Little Ute Creek, CO & $\mathrm{Y}$ & 2,792 & 1,391 & --- & --- & --- & --- & --- & 4.21 \\
\hline 29 & Sangre de Cristo Creek, CO & Y & 2,473 & 28,392 & 24.32 & Exposed & 18.49 & Exposed & 3.48 & 1.41 \\
\hline 30 & West Indian Creek, CO & $\mathrm{Y}$ & 2,606 & 6,797 & 18.35 & 20.08 & 13.90 & 14.72 & 1.16 & 0.20 \\
\hline 31 & Wagon Creek, CO & $\mathrm{Y}$ & 2,641 & 3,902 & 18.65 & 19.31 & 14.98 & 14.82 & 0.60 & 0.07 \\
\hline 32 & Sangre de Cristo Creek, CO & $\mathrm{Y}$ & 2,568 & 10,894 & --- & --- & --- & --- & --- & 1.70 \\
\hline 33 & Placer Creek, CO & $\mathrm{Y}$ & 2,608 & 5,744 & 20.88 & 19.14 & 14.89 & 15.07 & 2.37 & 1.17 \\
\hline 34 & Trinchera Creek,CO & $\mathrm{Y}$ & 2,641 & 7,762 & 15.46 & 17.23 & 11.11 & 11.94 & 7.52 & 5.93 \\
\hline 35 & North Fork Trinchera Creek, CO & $\mathrm{Y}$ & 2,673 & 4,094 & 16.71 & 17.56 & 12.60 & 12.75 & 1.34 & 0.75 \\
\hline 36 & Deep Canyon Creek, CO & $\mathrm{Y}$ & 3,125 & 399 & 13.04 & Lost & 7.44 & Lost & 0.43 & 0.29 \\
\hline 37 & North Fork Vallegos Creek, CO & $\mathrm{Y}$ & 2,725 & 2,971 & --- & --- & --- & --- & --- & 10.36 \\
\hline 38 & South Fork Vallegos Creek, CO & $\mathrm{Y}$ & 2,668 & 2,200 & --- & --- & --- & --- & --- & 0.69 \\
\hline 39 & Alamosito Creek, $\mathrm{CO}$ & Y & 2,796 & 1,294 & 15.09 & 15.34 & 11.77 & 11.65 & 1.20 & 0.83 \\
\hline 40 & Torcido Creek, CO & Y & 2,961 & 1,208 & 16.49 & 16.43 & 13.78 & 13.32 & 0.22 & 0.10 \\
\hline 41 & Jaroso Creek, CO & $\mathrm{Y}$ & 2,932 & 1,203 & 15.65 & 16.20 & 12.61 & 12.59 & 1.10 & 0.82 \\
\hline 42 & Cuates Creek, CO & $\mathrm{Y}$ & 2,691 & 1,282 & 14.07 & 14.65 & 12.04 & 12.38 & 0.51 & 0.75 \\
\hline 43 & Tio Grande, NM & $\mathrm{Y}$ & 2,749 & 2,589 & --- & 24.52 & --- & 17.64 & --- & 0.25 \\
\hline 44 & Rio Nutrias, NM & $\mathrm{Y}$ & 2,804 & 441 & --- & --- & --- & --- & --- & 0.31 \\
\hline 45 & Tanques Creek, NM & $\mathrm{Y}$ & 2,813 & 608 & --- & --- & --- & --- & --- & 0.27 \\
\hline 46 & Oiser Creek, CO & Y & 2,931 & 1,066 & 19.69 & 18.32 & 14.20 & 13.37 & 0.12 & 0.74 \\
\hline 47 & Cascade Creek, CO & $\mathrm{Y}$ & 2,970 & 654 & 18.76 & Lost & 14.37 & Lost & 0.45 & 0.39 \\
\hline 48 & Rio de los Pinos, CO & $\mathrm{Y}$ & 3,436 & 216 & --- & --- & --- & --- & --- & 8.49 \\
\hline 49 & Lake Fork Conejos Creek, CO & Y & 2,945 & 1,976 & --- & 20.77 & --- & 14.82 & 1.5 & 4.71 \\
\hline 50 & Richardo Creek, NM & $\mathrm{Y}$ & 2,554 & 4,748 & 18.06 & 19.65 & 13.46 & 14.48 & 2.53 & 2.36 \\
\hline 51 & Little Vermejo Creek, NM & $\mathrm{Y}$ & 2,559 & 2,972 & 22.82 & 24.94 & 15.77 & 16.51 & 0.23 & 0.83 \\
\hline 52 & McCrystal Creek, NM & $\mathrm{Y}$ & 2,440 & 2,726 & 25.07 & Exposed & 19.01 & Exposed & 0.22 & 0.34 \\
\hline 53 & Middle Ponil Creek, NM & Y & 2,915 & 1,276 & --- & Lost & --- & Lost & --- & 0.15 \\
\hline 54 & East Fork Luna Creek, NM & $\mathrm{Y}$ & 2,713 & 1,279 & --- & --- & --- & --- & --- & 0.06 \\
\hline 55 & Canones Creek, NM & $\mathrm{Y}$ & 2,473 & 4,325 & 19.75 & 19.56 & 15.82 & 15.46 & 0.49 & 0.88 \\
\hline
\end{tabular}


Table 1. Landscape, stream temperature, and summer baseflow metrics for study streams within the current distribution of Rio Grande cutthroat trout. Values highlighted in red indicate water temperature values that exceed Colorado's Cold Water Tier 1 water temperature criteria (Todd and others, 2008). Values highlighted in blue indicate baseflow measurements determined "precipitation affected," as defined by the accumulation of more than $1.3 \mathrm{~cm}$ of precipitation measured at the nearest SNOw TELemetry station on the day of the discharge measurement combined with the 2 days prior. - Continued

[RGCT, Rio Grande cutthroat trout present (Y) or not present but considered potential restoration streams (N); Elevation (m), Drainage area (ha), 2-hr Max = yearly maximum 2-hour running mean; MWAT, maximum weekly average temperature; $\mathrm{Q}=$ summer baseflow discharge (cubic feet per second); "---" refers to data not collected; "Exposed" refers to a data logger that was exposed to air temperature at some point during the year and data is not reported; "Lost" refers to data loggers removed by vandalism or storm event]

\begin{tabular}{|c|c|c|c|c|c|c|c|c|c|c|}
\hline Site & $\begin{array}{l}\text { Stream name, } \\
\text { state }\end{array}$ & RGCT & $\begin{array}{l}\text { Elevation } \\
(\mathrm{m})\end{array}$ & $\begin{array}{c}\text { Drainage } \\
\text { area } \\
\text { (ha) }\end{array}$ & $\begin{array}{c}2-h r \text { max } \\
\left({ }^{\circ} \mathrm{C}\right) \\
2010\end{array}$ & $\begin{array}{c}\text { 2-hr max } \\
\left({ }^{\circ} \mathrm{C}\right) \\
2011\end{array}$ & $\begin{array}{c}\text { MWAT } \\
\left({ }^{\circ} \mathrm{C}\right) \\
2010\end{array}$ & $\begin{array}{l}\text { MWAT } \\
\left({ }^{\circ} \mathrm{C}\right) \\
2011\end{array}$ & $\begin{array}{c}0 \\
\text { (cfs) } \\
2010\end{array}$ & $\begin{array}{c}0 \\
\text { (cfs) } \\
2011\end{array}$ \\
\hline 56 & Canones Creek, NM & $\mathrm{Y}$ & 2,555 & 3,338 & --- & 23.53 & --- & 15.89 & 0.50 & 0.75 \\
\hline 57 & El Rito Creek, NM & $\mathrm{Y}$ & 2,576 & 6,477 & 26.33 & --- & 18.74 & --- & 0.86 & 1.74 \\
\hline 58 & Canjlion Creek, NM & $\mathrm{Y}$ & 2,831 & 1,247 & Lost & Lost & Lost & Lost & 0.24 & 0.56 \\
\hline 59 & Wolf Creek, NM & $\mathrm{Y}$ & 2,940 & 1,071 & --- & --- & --- & --- & --- & 0.74 \\
\hline 60 & Rio de Truchas, NM & $\mathrm{Y}$ & 2,610 & 1,198 & --- & --- & --- & --- & --- & 2.96 \\
\hline 61 & Rio San Leonardo, NM & $\mathrm{Y}$ & 2,727 & 730 & --- & --- & --- & --- & --- & 0.92 \\
\hline 62 & Rio de las Trampas, NM & $\mathrm{Y}$ & 2,734 & 1,489 & --- & --- & --- & --- & --- & 3.37 \\
\hline 63 & Indian Creek, NM & Y & 2,774 & 551 & --- & --- & --- & --- & --- & 0.31 \\
\hline 64 & Jicarita Creek, NM & $\mathrm{Y}$ & 2,735 & 784 & --- & 14.76 & --- & 11.48 & --- & 1.64 \\
\hline 65 & Middle Fork Rio Santa Barbara, NM & $\mathrm{Y}$ & 2,853 & 4,138 & Lost & Lost & Lost & Lost & --- & 7.80 \\
\hline 66 & West Fork Rio Santa Barbara, NM & $\mathrm{Y}$ & 2,842 & 2,498 & --- & 15.77 & --- & 10.17 & --- & 4.98 \\
\hline 67 & East Fork Rio Santa Barbara, NM & Y & 3,148 & 1,479 & 14.31 & --- & 10.50 & --- & --- & --- \\
\hline 68 & Osha Canyon, NM & $\mathrm{Y}$ & 2,419 & 1,631 & --- & --- & --- & --- & --- & 0.23 \\
\hline 69 & Rito Angostura, NM & $\mathrm{Y}$ & 2,935 & 1,392 & Lost & --- & Lost & --- & 0.22 & --- \\
\hline 70 & Alamitos Creek, NM & $\mathrm{Y}$ & 2,951 & 1,788 & --- & 18.56 & --- & 12.40 & 0.06 & 1.92 \\
\hline 71 & Policarpio Creek, NM & $\mathrm{Y}$ & 2,772 & 779 & 15.93 & 16.53 & 11.23 & 11.19 & 0.46 & 0.62 \\
\hline 72 & Rio Grande del Rancho, NM & $\mathrm{Y}$ & 2,928 & 1,068 & --- & --- & --- & --- & --- & 0.52 \\
\hline 73 & Frijoles Creek, NM & Y & 2,923 & 804 & --- & --- & --- & --- & --- & 0.55 \\
\hline 74 & Yerba Creek, NM & $\mathrm{Y}$ & 2,516 & 619 & --- & --- & --- & --- & --- & 0.20 \\
\hline 75 & Manzanita Creek, NM & Y & 2,501 & 588 & --- & 7.36 & --- & 6.21 & 0.28 & 0.22 \\
\hline 76 & Italianos Creek, NM & $\mathrm{Y}$ & 2,677 & 581 & 15.57 & 15.78 & 11.87 & 11.92 & 0.50 & 0.32 \\
\hline 77 & Gavilan Creek, NM & Y & 2,775 & 764 & --- & --- & --- & --- & --- & 0.80 \\
\hline 78 & San Cristobal Creek, NM & $\mathrm{Y}$ & 2,497 & 1,200 & 12.74 & 14.24 & 10.78 & 11.44 & 0.90 & 0.45 \\
\hline 79 & Columbine Creek, NM & $\mathrm{Y}$ & 2,435 & 4,164 & 12.55 & 13.16 & 9.52 & 10.12 & 7.13 & 2.57 \\
\hline 80 & Columbine Creek, NM & $\mathrm{Y}$ & 2,583 & 1,451 & --- & 13.40 & --- & 10.37 & 1.26 & 1.17 \\
\hline 81 & Placer Fork, NM & Y & 2,581 & 1,324 & --- & 11.42 & --- & 9.43 & 3.10 & 1.11 \\
\hline 82 & Cabresto Creek, NM & $\mathrm{Y}$ & 2,852 & 2,415 & 16.23 & 17.40 & 11.66 & 11.81 & 0.43 & 0.55 \\
\hline
\end{tabular}


Table 1. Landscape, stream temperature, and summer baseflow metrics for study streams within the current distribution of Rio Grande cutthroat trout. Values highlighted in red indicate water temperature values that exceed Colorado's Cold Water Tier 1 water temperature criteria (Todd and others, 2008). Values highlighted in blue indicate baseflow measurements determined "precipitation affected," as defined by the accumulation of more than $1.3 \mathrm{~cm}$ of precipitation measured at the nearest SNOw TELemetry station on the day of the discharge measurement combined with the 2 days prior. - Continued

[RGCT, Rio Grande cutthroat trout present (Y) or not present but considered potential restoration streams (N); Elevation (m), Drainage area (ha), 2-hr Max = yearly maximum 2-hour running mean; MWAT, maximum weekly average temperature; $\mathrm{Q}$ = summer baseflow discharge (cubic feet per second); "---" refers to data not collected; "Exposed" refers to a data logger that was exposed to air temperature at some point during the year and data is not reported; "Lost" refers to data loggers removed by vandalism or storm event]

\begin{tabular}{|c|c|c|c|c|c|c|c|c|c|c|}
\hline Site & $\begin{array}{c}\text { Stream name, } \\
\text { state }\end{array}$ & RGCT & $\begin{array}{l}\text { Elevation } \\
\text { (m) }\end{array}$ & $\begin{array}{c}\text { Drainage } \\
\text { area } \\
\text { (ha) }\end{array}$ & $\begin{array}{c}\text { 2-hr max } \\
\left({ }^{\circ} \mathrm{C}\right) \\
2010\end{array}$ & $\begin{array}{c}\text { 2-hr max } \\
\left({ }^{\circ} \mathrm{C}\right) \\
2011\end{array}$ & $\begin{array}{c}\text { MWAT } \\
\left({ }^{\circ} \mathrm{C}\right) \\
2010\end{array}$ & $\begin{array}{c}\text { MWAT } \\
\left({ }^{\circ} \mathrm{C}\right) \\
2011\end{array}$ & $\begin{array}{c}0 \\
\text { (cfs) } \\
2010\end{array}$ & $\begin{array}{c}0 \\
\text { (cfs) } \\
2011\end{array}$ \\
\hline 83 & Cabresto Creek, NM & $\mathrm{Y}$ & 3,088 & 906 & --- & 19.20 & --- & 12.65 & 0.09 & 0.09 \\
\hline 84 & Comanche Creek, NM & $\mathrm{Y}$ & 2,728 & 10,941 & 23.83 & 25.13 & 16.77 & 16.7 & 0.76 & 0.70 \\
\hline 85 & Comanche Creek, NM & $\mathrm{Y}$ & 2,780 & 7,440 & --- & 24.12 & --- & 15.95 & 0.80 & 0.25 \\
\hline 86 & Little Costilla Creek, NM & $\mathrm{Y}$ & 2,785 & 1,398 & 17.76 & 19.65 & 12.98 & 13.03 & 0.47 & 0.32 \\
\hline 87 & Comanche Creek, NM & Y & 2,816 & 5,078 & Exposed & Exposed & Exposed & Exposed & 0.08 & 0.15 \\
\hline 88 & Grassy Creek, NM & $\mathrm{Y}$ & 2,825 & 474 & Lost & Lost & Lost & Lost & --- & --- \\
\hline 89 & Comanche Creek, NM & Y & 2,852 & 1,352 & 24.51 & 26.24 & 16.78 & 16.25 & 0.04 & 0.01 \\
\hline 90 & Vidal Creek, NM & $\mathrm{Y}$ & 2,854 & 2,477 & 22.90 & 22.99 & 16.30 & 15.01 & 0.04 & 0.02 \\
\hline 91 & Costilla Creek, NM & $\mathrm{N}$ & 2,729 & 17,526 & --- & 22.51 & --- & 16.41 & --- & 8.66 \\
\hline 92 & La Queva Creek, NM & Y & 2,745 & 852 & --- & --- & --- & --- & --- & 0.09 \\
\hline 93 & Powderhouse Creek, NM & Y & 2,948 & 903 & 18.19 & 17.89 & 12.50 & 12.84 & 0.16 & 0.10 \\
\hline 94 & Santistevan Creek, NM & $\mathrm{N}$ & 2,885 & 592 & --- & 16.12 & --- & 11.75 & 0.75 & 0.54 \\
\hline 95 & Casias Creek, NM & $\mathrm{N}$ & 2,885 & 4,157 & 17.62 & 20.48 & 12.05 & 13.38 & 4.83 & 3.88 \\
\hline 96 & Casias Creek, NM & $\mathrm{N}$ & 2,988 & 1,883 & --- & 17.55 & --- & 11.47 & 1.19 & 2.08 \\
\hline 97 & Costilla Creek, NM & $\mathrm{Y}$ & 3,097 & 1,678 & 22.39 & 23.22 & 13.24 & 13.38 & 0.67 & 0.97 \\
\hline 98 & West Fork Costilla Creek, NM & $\mathrm{Y}$ & 3,149 & 481 & 19.21 & 19.22 & 11.40 & 11.04 & 0.23 & 0.50 \\
\hline 99 & East Fork Costilla Creek, NM & Y & 3,149 & 550 & 20.25 & 22.51 & 11.66 & 12.17 & 0.16 & 0.34 \\
\hline 100 & Rio de las Vacas, NM & $\mathrm{Y}$ & 2,754 & 3,487 & --- & --- & --- & --- & --- & 0.39 \\
\hline 101 & Rio de las Palomas, NM & $\mathrm{Y}$ & 2,571 & 1,120 & --- & --- & --- & --- & --- & 0.02 \\
\hline 102 & La Jara Creek, NM & Y & 2,451 & 1,394 & --- & --- & --- & --- & --- & 0.58 \\
\hline 103 & Dalton Creek, NM & $\mathrm{Y}$ & 2,307 & 2,867 & --- & --- & --- & --- & --- & 0.40 \\
\hline 104 & Panchuela Creek, NM & $\mathrm{N}$ & 2,567 & 5,630 & 15.65 & 16.26 & 12.01 & 12.35 & --- & --- \\
\hline 105 & Cave Creek, NM & $\mathrm{N}$ & 2,642 & 1,820 & --- & 14.33 & --- & 11.92 & --- & 3.63 \\
\hline 106 & Jack's Creek, NM & Y & 2,534 & 1,851 & 16.37 & 17.03 & 12.70 & 13.57 & 1.07 & 0.56 \\
\hline 107 & Jack's Creek, NM & $\mathrm{Y}$ & 3,147 & 654 & Exposed & Exposed & Exposed & Exposed & 0.02 & 0.07 \\
\hline 108 & Pine Lodge Creek, NM & $\mathrm{Y}$ & 1,923 & 656 & --- & --- & --- & --- & --- & 0.06 \\
\hline
\end{tabular}




\section{Quality Control}

\section{Stream and Air Temperature Data}

Water temperature data loggers (Onset Computer Corporation HOBO U22 Pro v2) were selected for measurement of both stream and air temperature. The Pro v2 has an operating range from -40 to $70{ }^{\circ} \mathrm{C}$ with an accuracy of 0.2 over a $0-50{ }^{\circ} \mathrm{C}$ range and a resolution of 0.02 at $25^{\circ} \mathrm{C}$ (Onset Computer Corporation, 2009). Before deployment, data loggers were calibrated by immersing each data logger into 0 and $25^{\circ} \mathrm{C}$ water baths for $1 \mathrm{~h}$ (Schuett-Hames and others, 1999; Dunham and others, 2005). During immersion, the data loggers recorded temperatures at 2-minute intervals, and these data were subsequently compared to data obtained with a calibrated digital thermometer (Traceable Waterproof Thermometer $-50-300{ }^{\circ} \mathrm{C}$ ). No data loggers showed any significant deviation from temperatures recorded by the thermometer at either 0 or $25^{\circ} \mathrm{C}$.

Once downloaded from the field, each stream record was quality-checked by examining periods of time when temperature increases were greater than $3{ }^{\circ} \mathrm{C}$ per hour, single temperature readings exceeded $29^{\circ} \mathrm{C}$, and (or) daily temperature ranges were in excess of $15^{\circ} \mathrm{C}$. When data from a stream record exhibited these aforementioned responses, the data were reexamined and subsequently removed from further analysis if the data could not be adequately explained. For each stream record, hourly data were used to calculate individual daily (24-h) average temperatures. In addition, 2-h rolling averages were used to identify annual temperature daily minimums and maximums (2-hr min and max; daily maximum (DM)) and annual maximum weekly average temperatures (maximum annual value of the rolling average of mean daily water temperatures, MWAT, over a 7-day period) were calculated. When a stream record contained inadequate data to calculate representative summary metrics, the record was not included. For example, in streams that did not log summer water temperatures (for example, West Alder Creek in 2010 [Site 1]), annual temperature maxima and MWAT statistics were not calculated. Similarly, where only summer data were recorded, annual temperature minima and minimum weekly average temperature statistics were not calculated.

Air temperature data were assessed for accuracy through graphical analysis. Very few records revealed temperatures recorded out of seasonal context or malfunctioning data loggers, but any errors were removed, and the remaining data were used for further analysis. The same summary metrics for stream records (and exceptions) were then calculated for all air temperature datasets (appendix A).

\section{Stream-Discharge Data}

The logistics of monitoring stream discharge across all sites within a large geographical area precluded the use of one type of flow meter. Although Marsh-McBirney Flo-Mate and the Pygmy-MH meter differ in methodology, both are used for the measurement of flow in small, wadeable streams. The Marsh-McBirney meter uses an electromagnetic method to measure velocity within a range from -0.15 meter per second $(\mathrm{m} / \mathrm{sec})$ to $6.10 \mathrm{~m} / \mathrm{sec}$. The Pygmy-MH meter uses a vertical axis rotor to measure velocity and is recommended for shallow streams (Rantz and others, 1982) with a velocity range from $0.03 \mathrm{~m} / \mathrm{sec}$ to $1.50 \mathrm{~m} / \mathrm{sec}$. Soupir and others (2009) demonstrated that the Marsh-McBirney meter performed the best over a wider range of flows, whereas the Pygmy-MH meter exhibited decreased accuracy under lower velocities. To reduce variability caused by low velocities that could affect the accuracy of the Pygmy-MH meter, this meter was used in streams above the recommended range of discharge.

Water velocity was obtained as described above, and the total discharge at each site was calculated as follows:

$$
Q=\sum a_{n} V_{n}
$$

where

$$
\begin{aligned}
& \mathrm{a}_{\mathrm{n}} \quad \begin{array}{l}
\text { is the area of subsection } \mathrm{n} \text { calculated as the } \\
\text { depth } \mathrm{x} \text { width, }
\end{array} \\
& \mathrm{V}_{\mathrm{n}} \quad \begin{array}{c}
\text { is the velocity of subsection } \mathrm{n} \text { (Harrelson and } \\
\text { others, 1994). }
\end{array}
\end{aligned}
$$

The effect of precipitation on discharge was determined by examining precipitation records from nearby Natural Resources Conservation Service SNOw TELemetry (SNOTEL) stations. Sites that indicated cumulative precipitation within three days of the discharge measurement were marked as "precipitation affected" (more than $1.3 \mathrm{~cm}$ of precipitation measured at the nearest SNOTEL station on the day of the discharge measurement combined with 2 days prior). Additionally, six study sites were within proximity of streamgages operated by USGS or Colorado Division of Water Resources (CDWR) which take discharge measurements at regular intervals. At these locations, discharge was measured by using flow meters, and these values were compared to the corresponding measurement of USGS or CDWR streamgages at the time.

\section{Results}

\section{Water Temperature}

Several stream temperature data loggers were lost because of theft or high flows or were found to have been exposed to air (table 1). The remaining data loggers showed no instance of errors, resulting in an accumulation of more than 30,000 days of thermal data. Temperature profiles from populations of Rio Grande cutthroat trout (except for Manzanita Creek) are shown in figures 3 and 4. The seasonality of water temperatures in Rio Grande cutthroat 

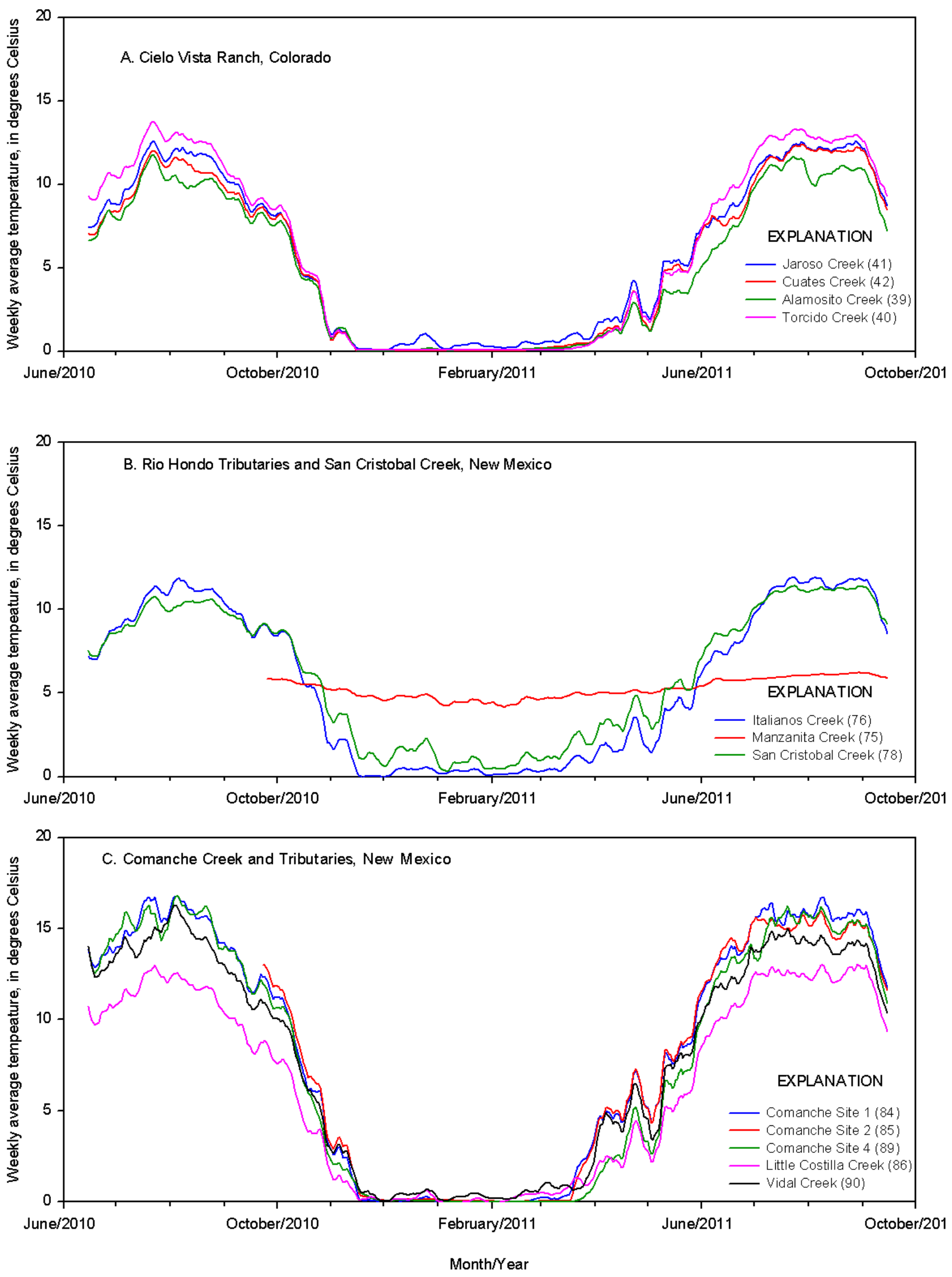

Figure 3. Weekly average temperature (WAT) within streams containing Rio Grande cutthroat trout (WAT is calculated as the 7-day running average of the daily average temperature for that day and the prior 6 days). 

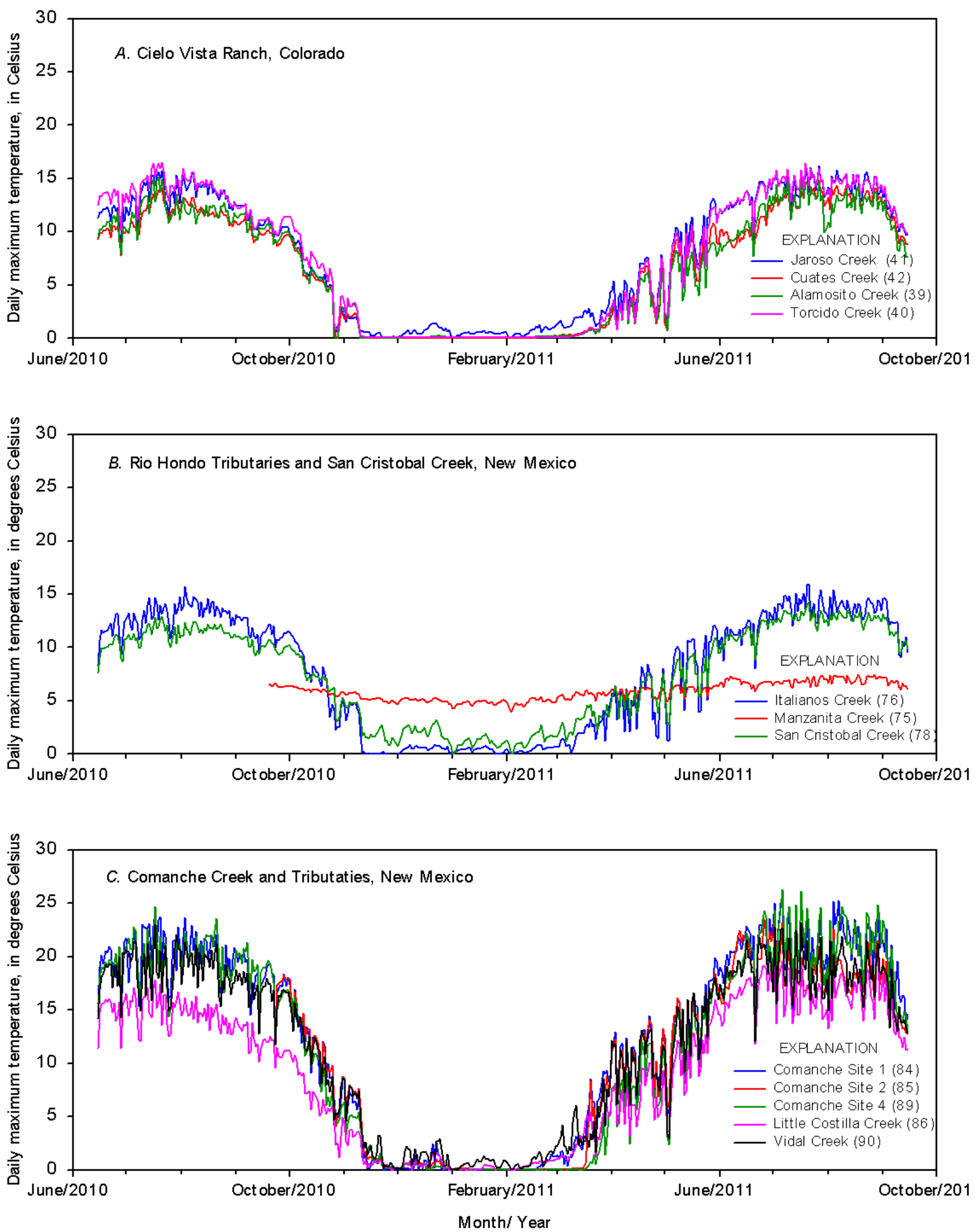

Figure 4. Daily maximum (DM) temperatures as measured in three regions within the distribution of Rio Grande cutthroat trout (DM is the maximum daily value of the running 2-hour average). 
trout streams is immediately evident, with the warmest water temperatures typically documented in the summer months of July and August. Within basins, many individual water temperature profiles reveal streams that are similarly responsive and sensitive to atmospheric drivers, with differences in magnitude among sites likely attributable to stream-specific differences such as riparian shading and streamflow volume (figs. $3 A$ and $3 C$ ). In strong contrast, Manzanita Creek demonstrated limited annual variability in water temperature, suggesting that the site was dominated by groundwater inputs compared to the other streams (fig. $3 B$ ). Profiles of daily maximum water temperature illustrated distinct diel patterns at some sites, whereas groundwater-dominated sites again demonstrated limited variability, including in the magnitude of day to day maximum temperature fluctuation (fig. 4).

At 46 sites containing Rio Grande cutthroat trout, MWATs in 2010 ranged from 7.4 to $19.0^{\circ} \mathrm{C}$ and in 2011 $(\mathrm{n}=54)$ ranged from 6.2 to $17.6^{\circ} \mathrm{C}$ (fig. 5; table 1). Maximum daily water temperatures (maximum 2-hr average) in these conservation populations ranged from 12.6 to $26.3{ }^{\circ} \mathrm{C}$ in 2010 and from 7.4 to $26.2^{\circ} \mathrm{C}$ in 2011 (fig. 5; table 1). Potential restoration streams displayed a similar range of water temperatures as currently occupied streams for both MWAT and daily maxima (fig. 5; table 1).

\section{Air Temperature}

Air temperature summary metrics are presented for individual sites in appendix A. In general, air temperature maxima and minima were higher and lower than water temperature maxima and minima measured at a given site.

\section{Comparison with Colorado's Water Temperature Criteria}

According to Colorado's water quality criteria for stream temperature, streams in which cutthroat trout are "expected to occur" are classified as Cold Tier 1 (Colorado Water Quality Control Commission, 2012). The criteria for Cold Tier 1 water temperature include both acute (daily maximum, DM) and chronic (MWAT) threshold values. The values for the Cold Tier 1 water temperature criteria vary seasonally, with winter (October-May: DM $=13^{\circ} \mathrm{C}$; MWAT $=9^{\circ} \mathrm{C}$ ) and summer (June-September: DM $=21.7^{\circ} \mathrm{C}$; MWAT $=17^{\circ} \mathrm{C}$ ) acute and chronic values defined. A comparison of water temperature metrics from our study streams with the summer Cold Tier 1 water temperature criteria indicated that temperatures in some currently occupied Rio Grande cutthroat trout streams exceed acute daily maximum temperature (2010: 22 percent; 2011: 17 percent) and (or) chronic maximum weekly average temperature (2010: 9 percent; 2011: 2 percent) Cold Tier 1 water temperature criteria (fig. 5; table 1). Several potential restoration streams were also documented to have temperatures that exceeded one or both Cold Tier 1 water temperature criteria (fig. 5; table 1).

\section{Discharge}

Of the discharge values taken at 64 sites in 2010, 58 were within Rio Grande cutthroat trout occupied habitat. Discharge values were taken at 103 sites in 2011, 93 of which were within Rio Grande cutthroat trout occupied habitat. In 2010, discharge measurements within Rio Grande cutthroat trout populations ranged from 0.02 cubic feet per second (cfs) to $7.52 \mathrm{cfs}$ (table 1). In 2011, discharge measurements in Rio Grande cutthroat trout streams ranged from $0.01 \mathrm{cfs}$ to $10.36 \mathrm{cfs}$. Although there was a wide range in discharge, the majority of the streams containing Rio Grande cutthroat trout streams had discharges less than $1.0 \mathrm{cfs}$ (table 1). Flow hydrographs for U.S. Geological Survey or Colorado Division of Water Resources monitored streamgage stations (within or in proximity to streams containing Rio Grande cutthroat trout) were used for comparison of measured discharge values used in this study (fig. 6). Points denoted on the figures reflect the measured discharge value at nearby stream temperature monitoring sites. Of note, our discharge values were comparable to those recorded at USGS or Colorado Division of Water Resources gage sites, providing support that our point measurements were adequately timed and sufficiently accurate to represent baseflow conditions within these streams (fig. 7). 

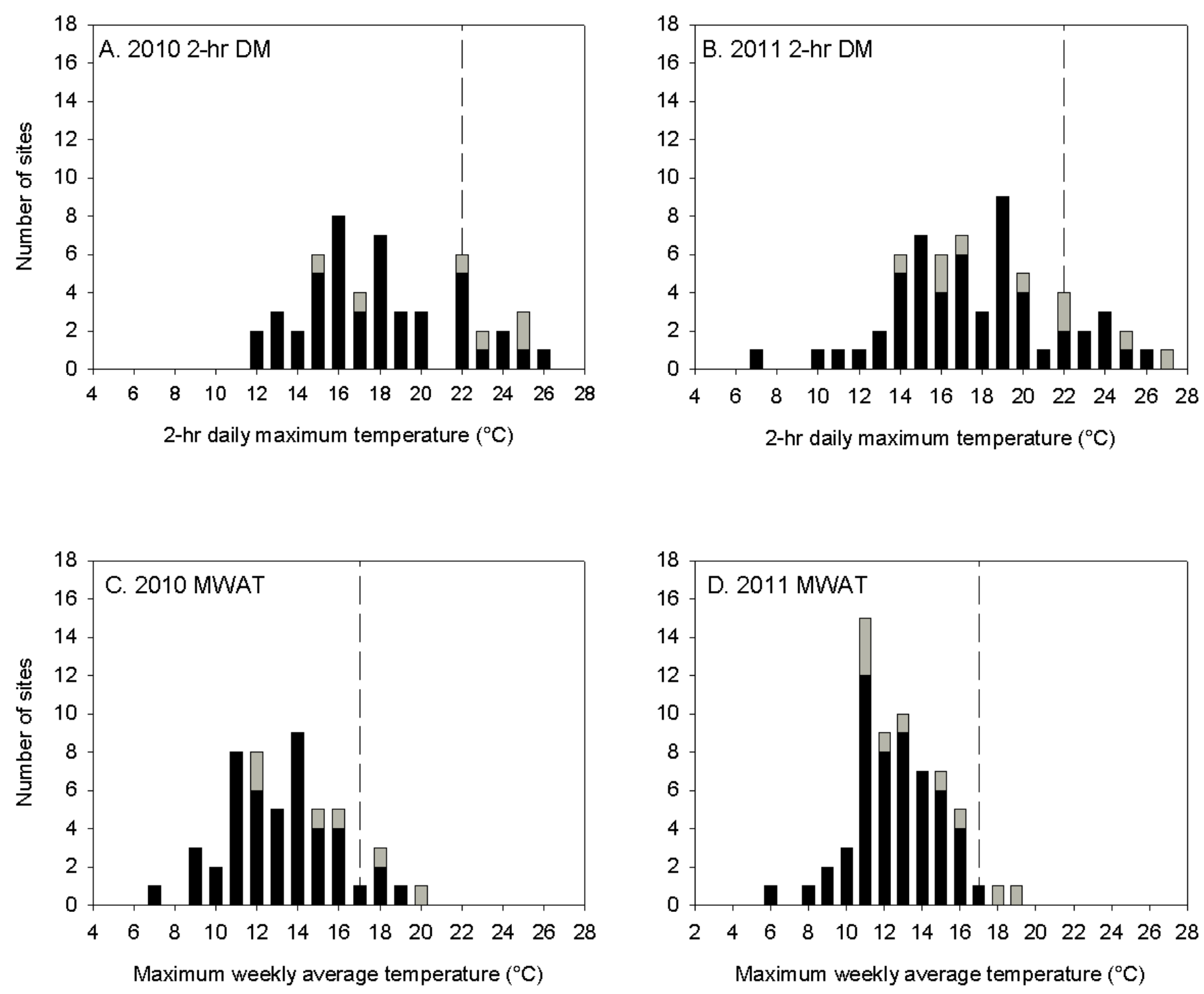

Figure 5. Summary water temperature metrics calculated from water temperature datasets collected in 2010 and 2011. Annual 2-hour daily maximum (DM) and maximum weekly average temperature (MWAT) are presented for each site. Gray bars represent potential/ current restoration streams, and black bars represent sites where Rio Grande cutthroat trout currently occur. Bins represent 1 degree Celsius $\left({ }^{\circ} \mathrm{C}\right.$ ) (for example, $6^{\circ} \mathrm{C}$ bin would represent sites with temperatures between 6 and $7^{\circ} \mathrm{C}$ ). Vertical dashed lines represent Colorado's Cold Tier 1 acute ( $\mathrm{A}$ and $\mathrm{B}$ ) and chronic ( $\mathrm{C}$ and $\mathrm{D})$ water temperature criteria. 

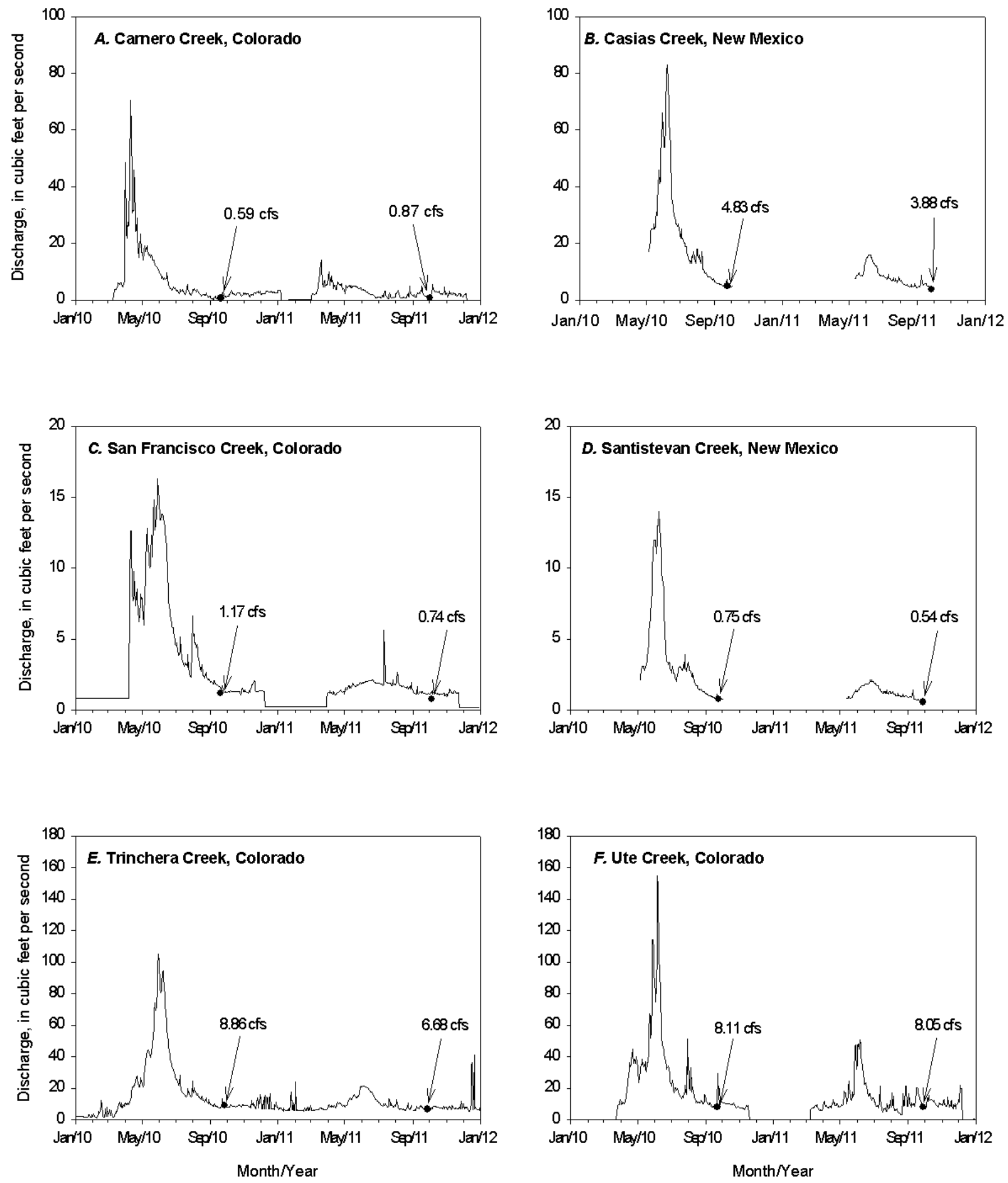

Figure 6. Flow hydrographs for U.S. Geological Survey or Colorado Division of Water Resources monitored gage stations (within or in close proximity to Rio Grande cutthroat trout streams) used for comparison of measured discharge values in this study. Points reflect the measured discharge value at nearby stream temperature monitoring sites. Note that only Trinchera Creek, Colorado, and San Francisco Creek, Colo., currently contain populations of Rio Grande cutthroat trout. 

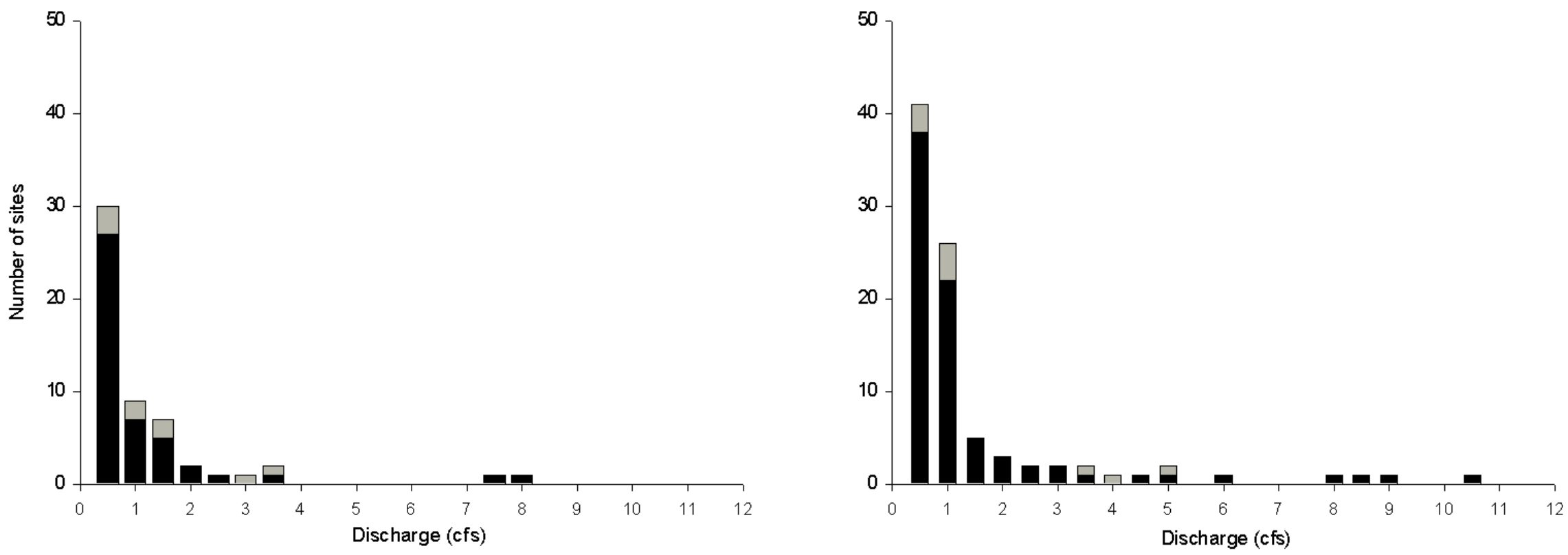

Figure 7. Measured baseflow discharge at sites within occupied Rio Grande cutthroat trout streams: $A, 2010(\mathrm{n}=54)$ and $B, 2011(\mathrm{n}=90)$. Bins reflect measured discharge 0.5 cubic feet per second (cfs) equal to or below the value (for example, $1.0 \mathrm{cfs}$ bin includes discharge values between $0.5 \mathrm{cfs}$ and $1.0 \mathrm{cfs}$ ). Measurements include mainstems near termini, important tributaries, and mainstems below the influence of important tributaries. Gray bars reflect discharges that were likely influenced by recent precipitation events, as defined by the accumulation of more than 1.3 centimeters $(\mathrm{cm})$ of precipitation measured at the nearest SNOw TELemetry (SNOTEL) station on the day of the discharge measurement combined with 2 days prior. 


\section{Summary}

At least 4 months of stream temperature data during summer conditions were collected within 46 populations of Rio Grande cutthroat trout in 2010 and 54 populations in 2011. Summer temperatures were also documented within 11 streams that represent potential restoration sites for the subspecies. We documented a large majority of streams containing populations of Rio Grande cutthroat trout that had no previous record of continual temperature records. When our data were evaluated in the context of the State of Colorado's water temperature criteria (Cold Tier 1), some populations appear to be at risk from high stream temperatures when we used biologically based acute (17-22 percent) and chronic (2-9 percent) water quality metrics. Summer water temperature profiles recorded at sites within current Rio Grande cutthroat trout habitat indicated that although the majority of currently occupied conservation streams have temperatures that fall well below these biologically based acute and chronic thermal thresholds, several sites may be at or approaching water temperatures considered stressful to cutthroat trout in general. Further, water temperature can affect the thermal suitability of potential Rio Grande cutthroat trout restoration sites.

Although significant variability in baseflow was documented among streams, a majority of streams containing populations of Rio Grande cutthroat exhibited very low baseflow discharge. Specifically, the majority of streams where the subspecies has been documented to occur exhibited stream baseflow discharge below 1.0 cubic feet per second in 2010 (74 percent) and 2011 (77 percent). Anecdotal observations of these streams indicate that low summer discharges result in reductions of available habitat for Rio Grande cutthroat trout that will likely be exacerbated during drought conditions.

\section{References}

Alves, J.E., Patten, K.A., Brauch, D.E., and Jones, P.M., 2008, Range-wide status report of Rio Grande cutthroat trout (Oncorhynchus clarkii virginalis) -2008: Colorado Division of Wildlife. (Also available at http://wildlife.state. co.us.)

Bear, E.A, McMahon, Thomas E., and Zale, Alexander V., 2007, Comparative thermal requirements of westslope cutthroat trout and rainbow trout: Implications for species interactions and development of thermal protection standards: Transactions of the American Fisheries Society v. 136, p. 1113-1121.

Behnke, R.J., 2002, Trout and salmon of North America: New York, The Free Press: New York, 359 p.
Colorado Water Quality Control Commission, 2012, Regulation 31-The basic standards and methodologies for surface water: Denver, Colo., Colorado Department of Public Health and the Environment.

De Staso, J. III, and Rahel, F.J., 1994, Influence of water temperature on interactions between juvenile Colorado River Cutthroat Trout and Brook Trout in a laboratory stream: Transactions of the American Fisheries Society, v. 123 , p. 289-297.

Dunham, J., Chandler, G., Rieman, B., and Martin, D., 2005, Measuring stream temperature with digital data loggers-A user's guide: Fort Collins, Colo., Gen. Tech. Rep. RMRSGTR-150WWW, U.S. Department of Agriculture, Forest Service, Rocky Mountain Research Station, 15 p.

Dunham, J., Schroeter, R., and Rieman, B., 2003, Influence of maximum water temperature on the occurrence of Lahontan cutthroat trout within streams: North American Journal of Fisheries Management, v. 23, p. 1042-1049.

Harrelson, C.C., Rawlins, C.L., and Potyondy, J.P., 1994, Stream channel reference sites-An illustrated guide to field technique: Fort Collins, Colo., Gen. Tech. Rep. RM-245, U.S. Department of Agriculture, Forest Service, Rocky Mountain Forest and Range Experiment Station, 61 p.

Harvey, B.C., Nakamoto, R.J., and White, J.L., 2006, Reduced streamflow lowers dry-season growth of rainbow trout in a small stream: Transactions of the American Fisheries Society, v. 135, p. 998-1005.

Harvey, B.C., and Stewart, A.J., 1991, Fish size and habitat depth relationships in headwater streams: Oecologia, v. 87, p. 336-342.

Hoerling, M., and Eischeid, J., 2007, Past peak water in the Southwest: Southwest Hydrology, v. 6, p. 18-19, 35.

Intergovernmental Panel on Climate Change (IPCC), 2007, Climate change 2007-Synthesis report: accessed November 15, 2009 at www.ipcc.ch.

Jobling, M., 1997, Temperature and growth-Modulation of growth rate via temperature change, in Wood, C.M., and McDonald, D.G., eds., Global Warming-Implications for freshwater and marine fish: Cambridge University Press.

Lake, P.S., 2003, Ecological effects of perturbation by drought in flowing waters: Freshwater Biology, v. 48, p. 1161-1172.

Magnuson, J.J., Crowder, L.B., and Medvick, P.A., 1979, Temperature as an ecological resource: American Zoologist, v. 19 , no. 1, p. 331-343.

Onset Computer Corporation, 2009, HOBO U22 Water Temp Pro v2: Document \# 10366-C. 
Pritchard, V.L., and Cowley, D.E., 2006, Rio Grande cutthroat trout (Oncorhynchus clarkii virginalis) —A technical conservation assessment: USDA Forest Service, Rocky Mountain Region: accessed September 15, 2008 at http:// www.fs.fed.us/r2/projects/scp/assessments.

Rantz, S.E., and others, 1982, Measurement and computation of streamflow-Volume 1. Measurement of stage and discharge: U.S. Geological Survey Water-Supply Paper 2175,313 p.

RGCT Conservation Team, 2009, Conservation agreement for Rio Grande cutthroat trout (Oncorhynchus clarkii virginalis) in the states of Colorado and New Mexico: Fort Collins, Colo., Colorado Division of Wildlife, $24 \mathrm{p}$.

Schuett-Hames, D., Pleus, A.E., Rashin, E., and Matthews, J., 1999, TFW Monitoring Program method manual for the stream temperature survey: Prepared for the Washington State Dept. of Natural Resources under the Timber, Fish, and Wildlife Agreement, 35 p.

Soupir, M.L., Mostaghimi, S., and Mitchem, C.E., Jr., 2009, A comparative study of stream-gaging techniques for lowflow measurements in two Virginia tributaries: Journal of the American Water Resources Association, v. 45, no. 1, p. 110-122.

Todd, A.S., Coleman, M.A., Konowal, A.M., May, M.K., Johnson, S., Vieira, N.K.M., and Saunders, J.F., 2008, Development of new water temperature criteria to protect Colorado's fisheries: Fisheries, v. 33, no. 9, p. 433-443.
U.S. Environmental Protection Agency (USEPA), 2004, Wadeable stream assessment_Field operations manual: Washington, D.C., EPA841-B-04-004, U.S. Environmental Protection Agency, Office of Water and Office of Research and Development.

U.S. Federal Register, 2008, Status review for Rio Grande cutthroat trout: Federal Register, v. 73, no. 94 (14 May 2008), p. 27900-27926.

Webb, B.W., Hannah, D.M., Moore, R.D., Brown, L.E., and Nobilis, F., 2008, Recent advances in stream and river temperature research: Hydrological Processes, v. 22, p. 902-918.

Winkle, W.V., Rose, K.A., Shuter, B.J., Jager, H.I., and Holcomb, B.D., 1997, Effects of climatic temperature change on growth, survival, and reproduction of rainbow trout-Predictions from a simulation model: Canadian Journal of Fisheries and Aquatic Sciences, v. 54, p. 2526-2512.

Zeigler, M.P., 2012, The effects of climate change on the future persistence of Rio Grande cutthroat trout: An assessment of recent climate change, thermal limits, and current and future stream temperature trends: Las Cruces, New Mexico State University, masters of science, $142 \mathrm{p}$.

Zeigler, M.P., Todd, A.S., and Caldwell, C.C., 2012, Evidence of recent climate change within the historic range of Rio Grande cutthroat trout-Implications for management and future persistence: Transactions of the American Fisheries Society, v. 141, p. 1045-1059. 


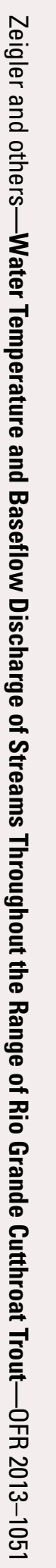

